\title{
Irrigation and organic and mineral fertilization in sunflower crop
}

\author{
Krishna Ribeiro Gomes', Thales Vinícius de Araújo Viana', Geocleber Gomes de Sousa²* \\ Fellype Rodrigo Barroso Costa', Benito Moreira de Azevedo'
}

'Federal University of Ceará, Fortaleza, CE, Brazil

${ }^{2}$ University of International Integration of Afro-Brazilian Lusophony, Redenção, CE, Brazil

*Corresponding author, e-mail: sousasolosgeo@hotmail.com

\begin{abstract}
The amount of available water to certain crops can play a direct influence on the expected effect of the application of fertilizers, whether mineral or organic origin. Thus, this work was performed in order to evaluate the effects of the application of different irrigation depths and organic and mineral fertilizers in the development and production of sunflower plants in Ceará state, Brazil. The experiment was carried out in full sun in pots containing Alfisol, in a completely randomized experimental design with a $5 \times 3$ factorial, five irrigation depths $(\mathrm{L} 1=50 \%, \mathrm{~L} 2=75 \%$, $\mathrm{L} 3=100 \%$, L4 and L5 $=125 \%=150 \%$ of the Class-A Tank evaporation ECA) and three fertilizations $(\mathrm{Fl}$ = organic, using aerobic fermentation of Bovine biofertilizer, $\mathrm{F} 2$ = mineral fertilizers, NPK-based and F3 = control without an addition of fertilizers with five replications. At 65 days after sowing (DAS), the following characteristics were analyzed: number of leaves, stem diameter, and plant height. In the maximum development of achenes (about 90 DAS), the plants were harvested to determine the head diameter, dry mass of 1000 seeds, dry mass of sunflower head, seed dry mass and crop yield. The different depths applied causing a significant effect in all the sunflower crop yield parameters being as low as the effect of the applied lower depth. The application of biofertilizers in plants provided increments similar to those provided by the application of mineral fertilizers in stem diameter, dry mass of the sunflower head, the head diameter and seed dry mass under different irrigation depths. Since most applied irrigation depth (150\% of the ECA), combined with the mineral fertilizer and bovine biofertilizer provided higher results in sunflower production.
\end{abstract}

Keywords: fertilization, Helianthus annuus L., water depth

\section{Introduction}

Sunflower (Helianthus annuus L.) is an annual plant of the family Asteraceae, originating from North and Central America, and has a relevant economic importance, being able to be used for human and animal feeding, in the production of edible vegetable oil and in the production of Biodiesel (Silva et al., 2007, Freitas et al., 2012).

Although several studies have been carried out with the sunflower crop, their water requirements are still not well defined, however, some authors have indicated the use of irrigation depths between 500 and $700 \mathrm{~mm}$ distributed over the crop cycle in order to obtain maximum expected crop yield (Nobre et al., 2010; Silva ef al., 2011). Applying water at levels lower than those required by the crop leads to waste since the expected production is not achieved (Viana et al., 2012). On the other hand, the excessive water application implies in the reduction of the crop yield, making its exploitation impracticable (Gomes et al., 2012).

Due to the low and uneven distribution of rainfall observed in the Brazilian semi-arid regions, as is the case in most of the Northeast region, special attention should be given to water management, estimating precisely the water needs of the crop, so that neither deficit nor excess occurs, as well as the most appropriate moment 
to irrigate, in order to maximize the efficiency of water use (Bilibio et al., 2010; Carvalho et al., 2013).

In addition to having the water needs met, to express maximum productive potential, plants need to grow in an environment where they have access to all the essential nutrients to their development.

Nitrogen, phosphorus, and potassium are the nutrients required in larger quantities by plants. Nitrogen is the most required mineral element, forming part of the constitution of amino acids and nucleic acids of plants. Phosphorus is part of compounds of high importance in plant cells that function as intermediates of respiration and photosynthesis processes. While potassium is highly important in the regulation of osmotic potential and fruit quality (Prado, 2008).

In an attempt to reduce costs with mineral fertilizers many farmers have been seeking alternative sources of nutrients for plant fertilization that provide adequate crop development. As a result, organic fertilizers of animal origin (biofertilizers) have gained more and more space in modern agriculture. For example, Sá et al. (2015) studying the application of biofertilizers in the sunflower crop, verified increases in production and improvement in soil chemical attributes.

Therefore, the objective of this work was to evaluate the effects of the application of five irrigation depths and organic and mineral fertilizers on the development and production of the sunflower crop.

\section{Materials and Methods}

The work was developed from August to November 2013 in an experimental area at Universidade Federal do Ceará, Ceará state, Brazil, $3^{\circ} 44^{\prime} 45^{\prime}$ 'S, $38^{\circ} 34^{\prime} 55^{\prime \prime}$ ' $\mathrm{W}$ and altitude of 19,5 $m$ asl. According to the Köppen classification, the climate is Aw' type, with a drier season in the winter (from June to September) and the maximum of rainfall occurs in the autumn (from March to June). The mean temperature, relative humidity, wind speed and rainfall observed over the experiment were $27.1^{\circ} \mathrm{C}, 70 \%, 4.1 \mathrm{~m} \mathrm{~s}^{-1}$ and $156 \mathrm{~mm}$, respectively.

The experiment was conducted in 60-liter pots filled with $84 \mathrm{~kg}$ of a sandy loam texture Alfisol (Argissolo Vermelho Amarelo - Embrapa, 2006). The physical and chemical attributes are shown in Table 1.

Table 1. Physical and chemical attributes of the substrate before application of the treatments

\begin{tabular}{ccccccccc}
\hline $\mathrm{N}$ & $\mathrm{P}$ & $\mathrm{K}$ & $\mathrm{SB}$ & $\mathrm{CEC}$ & $\mathrm{V}$ & $\mathrm{pH}$ & $\mathrm{EC}$ & $\mathrm{BD}$ \\
\hline & $\mathrm{g} \mathrm{kg}^{-1}$ & & & $\%$ & & & & $\mathrm{~g} \mathrm{~kg}^{-1}$ \\
\hline 0.05 & 0.014 & 0.10 & 48.3 & 65.6 & 74 & 6.4 & 0.33 & 1.4 \\
\hline SB= sum of bases; CEC= cation exchange capacity; $V=$ base saturation; & EC= electrical conductivity; $B \mathrm{BD}=$ soil bulk density.
\end{tabular}

The experiment was arranged in a completely randomized design, in a $5 \times 3$ factorial scheme, referring to five irrigation depths $\left(L_{1}-50 \%\right.$, $L_{2}-75 \%, L_{3}-100 \%, L_{4}-125 \%$ e $L_{5}-150 \%$ of the Class-A Tank evaporation - ECA), and three fertilizations, $\mathrm{Fl}$ - organic (using aerobic fermentation bovine biofertilizer), F2 - mineral (based on $100 \%$ of the NPK recommendation) and F3 - without fertilizer addition (control), with five replications, totaling 75 experimental units. Each of the five irrigation depths (L) combined with each of the three fertilizations (F) was considered as a treatment performed during the experiment, totaling 15 treatments.

The seeds of sunflower Embrapa 122 variety were sown at an average depth of
$5 \mathrm{~cm}$. After the establishment of the crop, approximately 10 days after sowing (DAS), thinning was performed leaving only one plant per pot. At that moment the treatments were applied in the culture with differentiation of the irrigation depths. Before that, the applied irrigation depth corresponded to $100 \%$ in all the plants of the experiment.

The total irrigation depths applied in each of the treatments during the experiment were as follows: $\mathrm{L} 1=452.7 \mathrm{~mm}$; $\mathrm{L} 2=631.1 \mathrm{~mm} ; \mathrm{L} 3$ $=809.5 \mathrm{~mm} ; \mathrm{L} 4=987.9 \mathrm{~mm}$ and $\mathrm{L} 5=1166.3 \mathrm{~mm}$, corresponding to the treatments: $50,75,100,125$ and $150 \%$ of the ECA, respectively.

Throughout the experiment, the soil moisture monitoring was carried out through 
tensiometers installed in the pots at approximately $20 \mathrm{~cm}$ depth. Readings were performed prior to irrigation. For quantification of the values of soil moisture was used a Sondaterra brand digital tensiometer. The average values of soil water tension in the evaluated pots during the experiment are observed in Table 2.

Table 2. Mean values of soil water tension during sunflower cultivation

\begin{tabular}{cccc}
\hline \multirow{2}{*}{ Irrigation depth } & \multicolumn{3}{c}{ Tension (kPa) } \\
\cline { 2 - 4 } & Control & Biofertilizer & Mineral \\
\hline L1 & -57.1 & -4.8 & -33.5 \\
L2 & -44.1 & -6.1 & -24.2 \\
L3 & -50.1 & -15.4 & -19.0 \\
L4 & -26.9 & -5.4 & -27.4 \\
L5 & -33.9 & -15.5 & -25.8 \\
\hline$L_{1}, L_{2}, L_{3}, L_{4}, L_{5}-50,75,100,125$ e 150\% of the ECA, respectively. & &
\end{tabular}

At 15 DAS the applications of mineral and organic fertilizers were started. In order to meet the nutritional requirements of the plants during the sunflower cycle, the maximum recommendation of the chemical fertilization indicated by Freitas et al. (2012) was adopted, which corresponded to $100 \mathrm{~kg} \mathrm{ha}^{-1}$ of $\mathrm{N}, 330 \mathrm{~kg}$ $\mathrm{ha}^{-1}$ of $\mathrm{P}_{2} \mathrm{O}_{5}$ and $150 \mathrm{~kg} \mathrm{ha}^{-1}$ of $\mathrm{K}_{2} \mathrm{O}$. As a reference, for a stand of 10,000 plants (Spacing $1.0 \times 1.0 \mathrm{~m}$ ) the maximum recommended dose per plant ${ }^{-1}$ in the crop cycle was: $10 \mathrm{~g} \mathrm{~N} ; 33 \mathrm{~g} \mathrm{P}_{2} \mathrm{O}_{5}$ and $15 \mathrm{~g}$ $\mathrm{K}_{2} \mathrm{O}$.

According to Table 1, the substrate provided only $0.05 ; 0.014 ; 0.10 \mathrm{~g} \mathrm{~kg}^{-1}$ of $\mathrm{N}, \mathrm{P}$ and $\mathrm{K}$, respectively. Multiplying the volume of the substrate ( $84 \mathrm{~L}$ ) by the soil bulk density $(1.4 \mathrm{~g} \mathrm{~kg}$ 1), $117.6 \mathrm{~g} \mathrm{~kg}^{-1}$ of mass was obtained, that is, the total $N, P$ and $K$ available for the plants before the application of the treatments was: 5.88; 11.76 and 7.05 (g plant-1), respectively. Therefore, the need for nutritional supplementation was $\mathrm{N}=$ 4,$12 ; \mathrm{P}=21.24 ; \mathrm{K}=7.95\left(\mathrm{~g} \mathrm{plant}^{-1}\right)$.

The simple anaerobic bovine biofertilizer was prepared using fresh bovine manure and water at a proportion of 1:1 during thirty days.
In order to obtain the anaerobic system, the mixture was placed in plastic containers of 240 liters leaving an empty space of 15 to $20 \mathrm{~cm}$ inside the container and hermetically closed. In the lid was fitted a hose with the other end dipped in a container with water at the height of $20 \mathrm{~cm}$, to allows the exit of gases (Penteado, 2007). The biofertilizer was supplied manually in 15 applications, distributed weekly, with a total volume applied in each treatment of 15 liters.

The nutrient contents ( $N, P, K, C a, M g$, $\mathrm{Fe}, \mathrm{Cu}, \mathrm{Zn}$, and $\mathrm{Mn}$ ) in the chemical composition of the dry matter of the biofertilizers are shown in Table 3. The analyses were carried out adopting the methodology suggested by Malavolta et al. (1997).

It was sought to provide the maximum recommendation for N, P and K (Silva et al., 2013) to try to meet the requirement of the crop from the chemical analysis of the substrate (Table 1) and biofertilizer (Table 3). The estimation of the total nutrient supply to the plants (substrate plus biofertilizers) in the different doses is showed in Table 4.

Table 3. Chemical characteristics of bovine biofertilizer with aerobic fermentation

\begin{tabular}{ccccccccccc}
\hline \multicolumn{10}{c}{} & \multicolumn{10}{c}{ Biofertilizer } \\
\hline & & $\left(\mathrm{g} \mathrm{L}^{-1}\right)$ & \multicolumn{1}{c}{$\left(\mathrm{mg} \mathrm{L}^{-1}\right)$} \\
\hline$(\mathrm{N}$ & $\mathrm{P}$ & $\mathrm{K}$ & $\mathrm{Ca}$ & $\mathrm{Mg}$ & $\mathrm{S})$ & $(\mathrm{Na}$ & $\mathrm{Fe}$ & $\mathrm{Cu}$ & $\mathrm{Zn}$ & $\mathrm{Mn})$ \\
\hline 0.26 & 0.51 & 1.21 & 0.17 & 3.04 & 0.17 & 0.78 & 47.99 & 0.22 & 16.05 & 10.07 \\
\hline
\end{tabular}

Table 4. Estimation of total nutrient supply in the sunflower crop cycle.

\begin{tabular}{|c|c|c|c|}
\hline Biofertilizers + substrate & $\mathrm{N}$ & $P$ & K \\
\hline & \multicolumn{3}{|c|}{ g 15 application ${ }^{-1}$} \\
\hline $1 \mathrm{~L}^{\text {week }}{ }^{-1}$ plant $^{-1}$ & 3.95 & 7.66 & 18.25 \\
\hline
\end{tabular}


The parameters plant height growth, stem diameter and number of leaves were evaluated when the plants were in the full blossoming at 65 DAS, according to the methodology proposed by Freitas et al. (2012). For measuring plant height and plant diameter, a measuring tape $(\mathrm{cm})$, and a digital caliper ( $\mathrm{mm}$ ) was used, respectively. The diameter of the stem was measured at the base of the plant.

At 90 DAS, at the time of harvest, using a millimeter ruler, the diameter of the sunflower head was measured. After drying, sunflower head dry mass (HDM), seed dry mass (SDM) and dry mass of 1000 seeds (1000SM) were determined according to Brazil (2009). From the values of seed dry mass was calculated the crop yield in $\mathrm{kg} \mathrm{ha}^{-1}$ multiplying the value found by the stand of sunflower plants per hectare.

The results were submitted to analysis of variance and regression, and the mean values were compared by Tukey's test ( $P<0.05)$, using Microsoft Office Excel (2003) applications and ASSISTAT software (SILVA, 2014a). In the regression analysis, the equations that best fit the data were chosen based on the regression significance coefficients at the $1 \%$ and $5 \%$ significance levels by the F-test, and the highest coefficient of determination $\left(R^{2}\right)$.

\section{Results and Discussion}

The mean squared values of plant height $(\mathrm{PH})$, stem diameter (SD) and number of leaves (NL) are showed in Table 5. It was verified that for plant height values there was a significant effect for irrigation depth, and fertilizer, however, there was no significant interaction between these factors. For the stem diameter values, it was observed that there was an interaction between the irrigation depth, and the fertilizers applied, and that there was no significant effect of any treatment for the number of leaves.

This effect on the number of leaves reveals that the plants were able to express, over the cycle, characteristics of recovery at the effects of the water deficiency in which they were exposed during the vegetative stage (Leite et al., 2005).

For the plant height, there was an isolated effect of water stress, showing a 2nd-degree polynomial model (Figure 1), and the maximum average plant height occurred when the applied irrigation depth corresponded to $126.3 \%$ of the ECA, reaching $48.2 \mathrm{~cm}$ height. This result reveals that there is variation in the soil water availability conditioned by the application of different irrigation depths. It is also observed that, although the crop is considered resistant to drought, it does not mean that its growth and development are not influenced by the soil water availability (Silva et al., 2007; Viana et al., 2012).

Increases in plant height values as a function of the increased irrigation depth were also verified by Viana et al. (2012). These authors affirm that the soil water availability is a limiting factor in the turgescence of the tissues, thus, affecting the plant morphology and physiology, being the height directly influenced by the water deficit. Therefore, the lowest values of plant height with the smallest irrigation depth may be explained by the reduction of the cellular expansion caused by the water deficit (Carvalho et al., 2013).

The mean values of plant height as a function of the fertilization are observed in Figure 2. It is verified that the plant height was influenced by the application of fertilizers and the difference was significant between the plants that received the organic fertilizer and the mineral one.

The best performance of the plants fertilized with the organic fertilizer can be explained by the fact that, when managed correctly, organic fertilizers improve the physical, chemical and biological conditions of the soil, and represent an efficient alternative in the reduction or even the elimination of dependence

Table 5. The mean squared values of sunflower plant height (PH), stem diameter (SD) and number of leaves (NL)

\begin{tabular}{ccccc}
\hline SV & DF & PH & SD & NL \\
& & $(\mathrm{cm})$ & $(\mathrm{mm})$ & $12.58^{\text {ns }}$ \\
Depth (L) & 4 & $335.24^{* *}$ & $107.02^{* *}$ & $1.69^{\text {ns }}$ \\
Fertilization (F) & 2 & $44.71^{*}$ & $20.64^{* *}$ & $3.92^{\text {ns }}$ \\
L x F & 8 & $26.10^{\text {ns }}$ & $7.54^{* *}$ & $6.08^{\text {ns }}$ \\
Treatments & 14 & $117.08^{* *}$ & $37.84^{* *}$ & 11.57 \\
Residuals & 60 & 12.94 & 2.31 & 1.92 \\
\hline Total & 74 & & 13.28
\end{tabular}




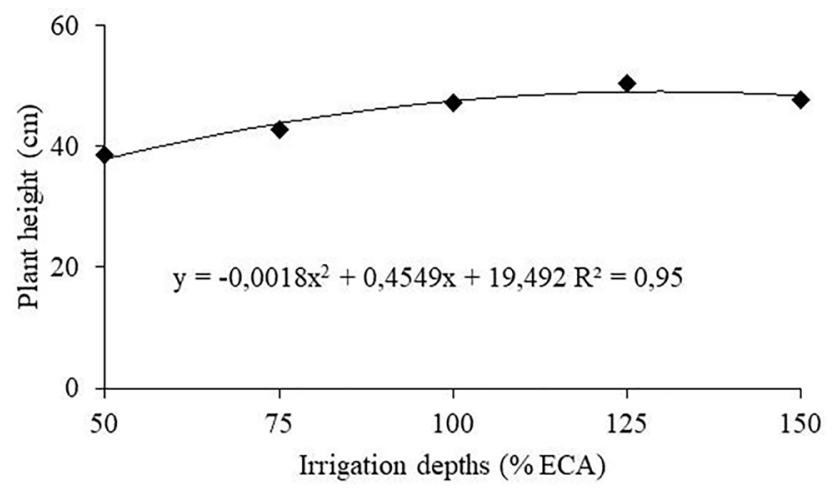

Figure 1. Mean values of sunflower plant height as a function of irrigation depths.

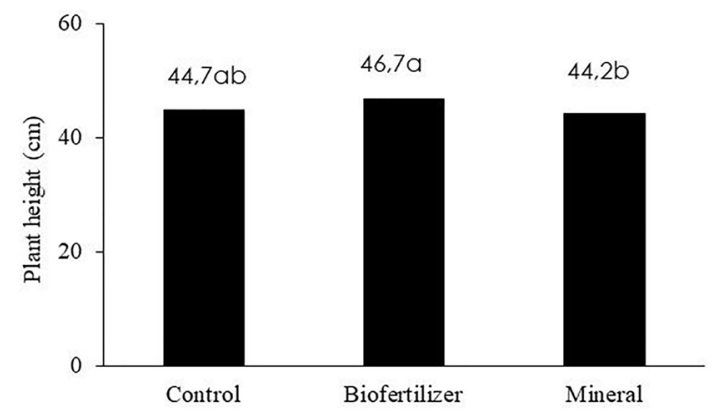

Figure 2. Mean values of sunflower plant height as a function of fertilizers applied

on chemical fertilizers (Penteado, 2007; Sousa et al., 2013).

Similarly, Souza et al. (2010) also verified that the use of biofertilizer in the sunflower crop provided increases in plant height values, these authors used wastewater in the irrigation of the plants, for them the best performance was due to the high availability of $N, P$ and $K$ existent in this type of water. By studying the development of sunflower plants under different doses of cattle manure and irrigation depths, Nobre et al. (2010) observed an increase in the height values of sunflower plants with the increase of applied fertilizer doses, however, they did not observe an interaction between the applied water depths and the fertilizer doses.

The interaction between the applied irrigation depths and the fertilizers in the stem diameter values is verified in Figure 3. It can be verified that the treatments fertilized with the bovine biofertilizer and with the mineral fertilization showed a linear model with an increase of the irrigation depths. The treatments that did not receive fertilization (control) showed a quadratic model, with a maximum stem diameter of 16.56 $\mathrm{mm}$ for an optimal water depth of $117.5 \%$ ECA.
Oliveira et al. (2010) argued that the adequate supply of water and nutrients to plants may be considered the most important factors in the crop development.

The superiority showed by the bovine biofertilizer in relation to the control treatment for this variable confirms the suggestion made by Penteado (2007), revealing that this organic input increases soil fertility and works as a plant growth promoter.

Regarding of irrigation depths, except for treatments without an addition of fertilizers, Viana et al. (2012) and Freitas et al. (2012) also found higher stem diameter values in plants that received treatment with the largest water depth (corresponding to $150 \%$ of the ECA). This effect shows that plants under water deficit, causes the closure of the stomata, reducing $\mathrm{CO}_{2}$ assimilation and, consequently, decreasing the physiological activities of the plants, thus resulting in a lower plant development (Silva et al., 2013).

On the other hand, studies involving interaction between mineral fertilizer and irrigation depths, showed contrasting results to this present study, as reported by Silva et al. (2014b) in sunflower crop and Carvalho et al. (2013) in 
Jatropha crop. These authors verified that there was an only isolated effect of irrigation depths for both cultures. The authors further emphasize that the simultaneous application of the mineral element via irrigation water can cause leaching.

The summary of the analysis of variance for the sunflower crop production as a function of the treatments is shown in Table 6. It can be verified that there was a significant interaction between the applied treatments (depths $x$ fertilizers) for the values of the sunflower head diameter, head dry mass, seed dry mass, and crop yield, whereas for the mass of 1000 seeds there was a significant effect only for the applied irrigation depths.

It was verified that the linear model was the one that best fit the treatments fertilized with the organic and mineral fertilizer, while the control (without fertilizer) the best fit was found for the quadratic polynomial model, showing the greatest values of the diameter of sunflower head $(11.61 \mathrm{~cm})$, when the irrigation depth corresponding to $113.5 \%$ of the ECA was applied (Figure 4).

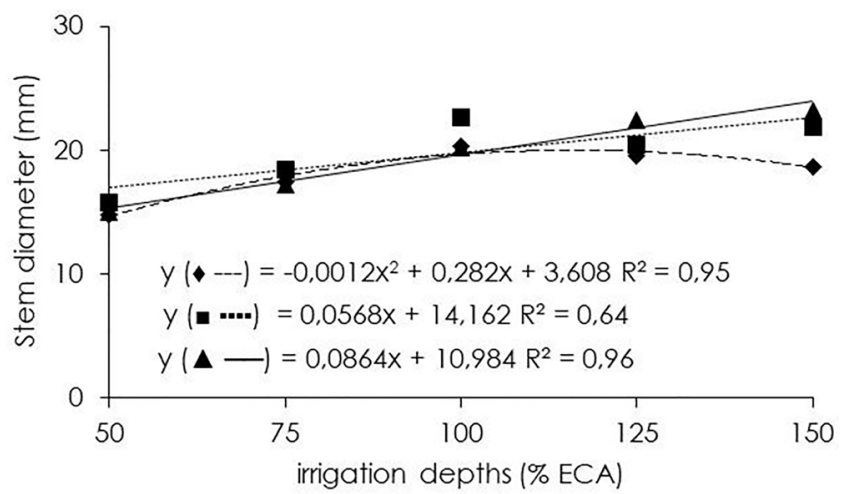

Figure 3. Stem diameter of sunflower plants ( - - ) without fertilizers, (.... ) bovine biofertilizer and ( $\mathbf{\Delta}-)$ mineral fertilizer, under different irrigation depths

Table 6. Summary of the analysis of variance for the production of sunflower crop, the diameter of sunflower head (DSH), sunflower head dry mass (HDM), seed dry mass (SDM), dry mass of 1000 seeds (1000SM), and crop yield.

\begin{tabular}{ccccccc}
\hline SV & DF & DSH (cm) & HDM (g) & SDM (g) & $1000 S M(g)$ & $\begin{array}{c}\text { Crop Yield } \\
\left(\mathrm{kg} \mathrm{ha}^{-1}\right)\end{array}$ \\
\hline Depth (L) & 4 & $23,83^{* *}$ & $5030,62^{* *}$ & $2419,72^{* *}$ & $1070,61^{* *}$ & $4200906,7^{* *}$ \\
Fertilization (F) & 2 & $5,7^{* *}$ & $728,81^{\text {ns }}$ & $657,75^{* *}$ & $59,81^{\text {ns }}$ & $1141928,2^{* *}$ \\
LxF & 8 & $1,61^{* *}$ & $635,91^{*}$ & $248,44^{* *}$ & $84,87^{\text {ns }}$ & $431331,9^{* *}$ \\
Treatments & 14 & $8,47^{* *}$ & $1904,81^{* *}$ & $927,28^{* *}$ & $362,93^{* *}$ & $1609867,1^{* *}$ \\
Residuals & 60 & 0,31 & 235,66 & 75,16 & 59,20 & 130486,1 \\
\hline Total & 74 & \multicolumn{7}{c}{16} \\
\hline CV (\%) & 4,78 & 18,84 \\
\hline SF- Sources of variation; DF- degrees of freedom; CV - coefficient of variation.
\end{tabular}

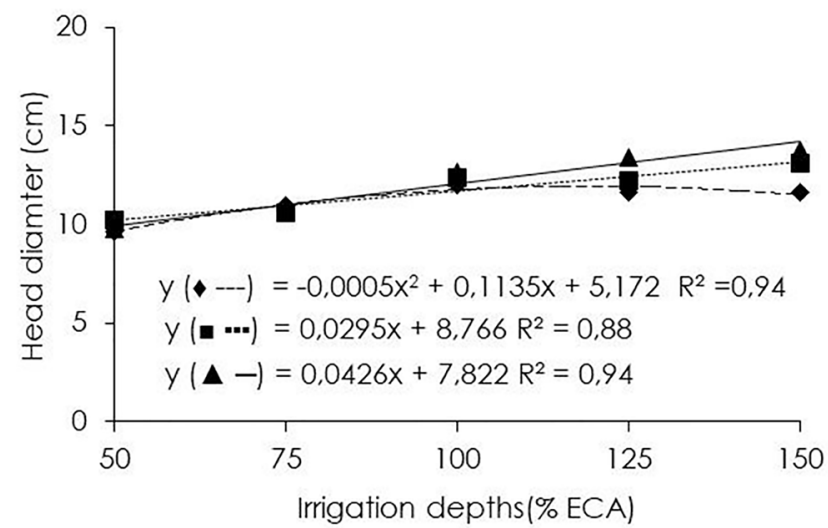

Figure 4. Diameter of sunflower head ( --$)$ without fertilizers,

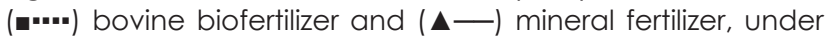
different irrigation depths 
The increase of water content in the soil provided the greatest diameter of sunflower head with and without an addition of fertilizers, revealing a positive effect of the interaction of these factors. It should be noted that the diameter of the head is a production component of great importance in the comparison of sunflower cultivars since it has a positive association with grain yield (Lobo and Grassi Filho, 2007) and with the amount of oil produced (Joner et al. Al., 2011).

Under field conditions, Silva et al. (2011) also verified influence on the application of different irrigation depths in the sunflower head diameter. Similarly, Gomes et al. (2010) also observed that the water increment contributed to the increase of the sunflower head diameter.

The mineral fertilization was more efficient in the nutritional aspect than the organic fertilizer with biofertilizer for the sunflower head diameter. It should be noted that some results were pertinent, as described by Santos et al. (2013) when evaluating sunflower production. These authors verified increases in the sunflower head diameter due to the application of doses of organomineral fertilizer. Likewise, some organic sources show positive effects, such as the cassava wastewater (manipueira) in sunflower (Dantas et al., 2016) and the bovine biofertilizer in melon plants (Santos et al., 2014)

Similar to the sunflower head diameter, the model that best fit for the head dry mass was the linear one for the treatments fertilized with the organic and mineral fertilizers and quadratic polynomial model for the control treatment, showing the highest values head dry mass (1 $19.47 \mathrm{~g}$ and $103.32 \mathrm{~g}$ ) when the irrigation depth corresponding to $150 \%$ of the ECA was applied in the treatments fertilized with mineral fertilizer and organic fertilizer, respectively (Figure 5).

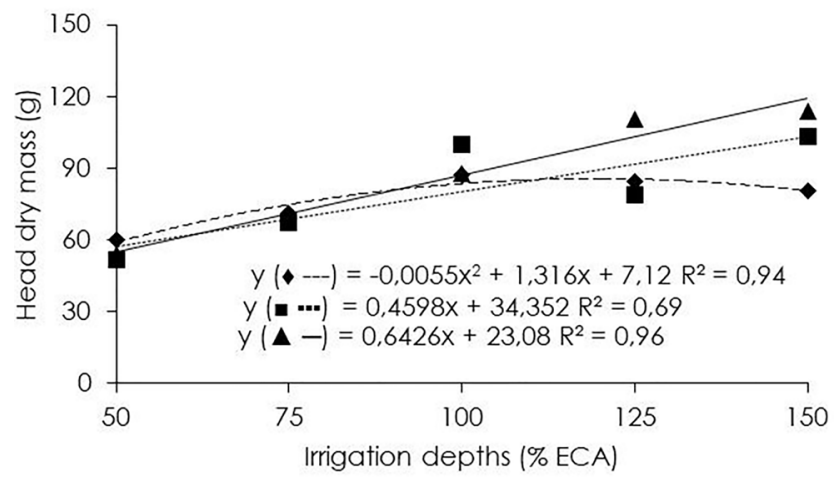

Figure 5. Sunflower Head dry mass, $(--)$ without fertilizers, $(\boldsymbol{n - . \cdot )}$ bovine biofertilizer and $(\boldsymbol{\Delta}-)$ ) mineral fertilizer, under different irrigation depths

The better performance of the mineral fertilization comparing to the biofertilizer and the control treatments may be related to the faster absorption and the accumulation of large amounts of nutrients, mainly nitrogen, phosphorus, and potassium by the sunflower crop (Santos et al., 2013). Confirming this information, Vasconcelos et al. (2015) found a positive effect of the application of mineral fertilizer (nitrogen) on soil whose the water content was close to the field capacity in sunflower crop.

Lobo et al. (2013) using sewage sludge as an organic source in sunflower plants observed a significant increase in the head dry mass of the studied plants. Lima et al. (2013) who studied irrigation depths with and without bovine biofertilizer, verified that the treatments that received this input showed greater increases for this variable in sesame crop.

Fertilization provides accumulation of large amounts of nutrients, mainly nitrogen, phosphorus and potassium in sunflower crop, that is, its deep root system provides greater exploitation and helps to improve the utilization of fertilizers and consequently higher dry mass of seeds (Nobre et al., 2010; Vasconcelos et al. 2015).

The model that best adjusted for the seed dry mass was the linear one for the treatments fertilized with organic and mineral fertilizers, and quadratic polynomial model for the control treatment, being observed higher values $(67.60$ 
$\mathrm{g}$ and $79.51 \mathrm{~g})$, when the irrigation depths corresponding to $150 \%$ of the ECA was applied to the plants fertilized with organic and mineral fertilization, respectively (Figure 6).

Similar to this present study, Silva et al. (2011) studying sunflower crop under different irrigation depths, also observed that the water increment contributed to the seed dry mass.

Regarding the fertilizer effect, the highest values in treatments with mineral fertilization are probably related to the soil gradual enrichment with macronutrients essential to the plants during the crop cycle (Santos et al., 2013). These authors concluded that the mineral fertilization provided an increase for the sunflower seed dry mass.

The mass of one thousand sunflower seeds (1000SM) as a function of the irrigation depths by dripping was adjusted to the linear model, $R^{2}$ equal to 0.93 (Figure 7).

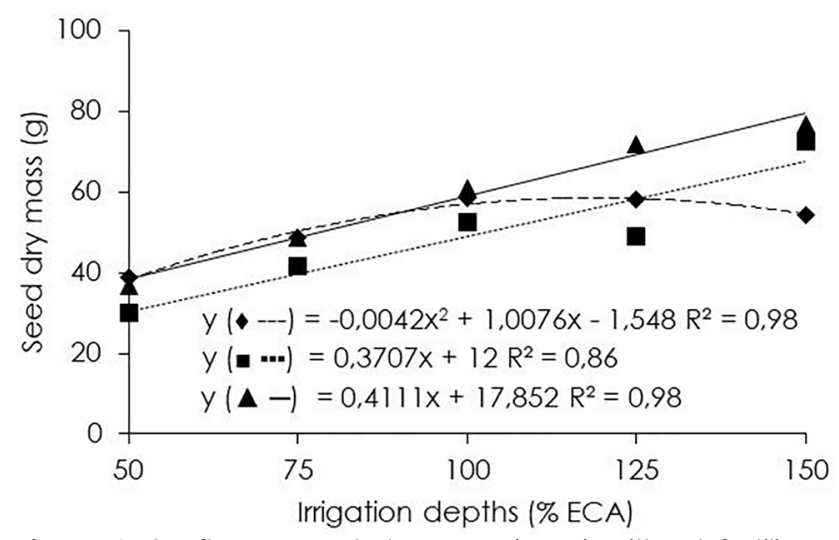

Figure 6. Sunflower seed dry mass ( $\$--)$ without fertilizers,

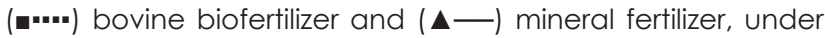
different irrigation depths

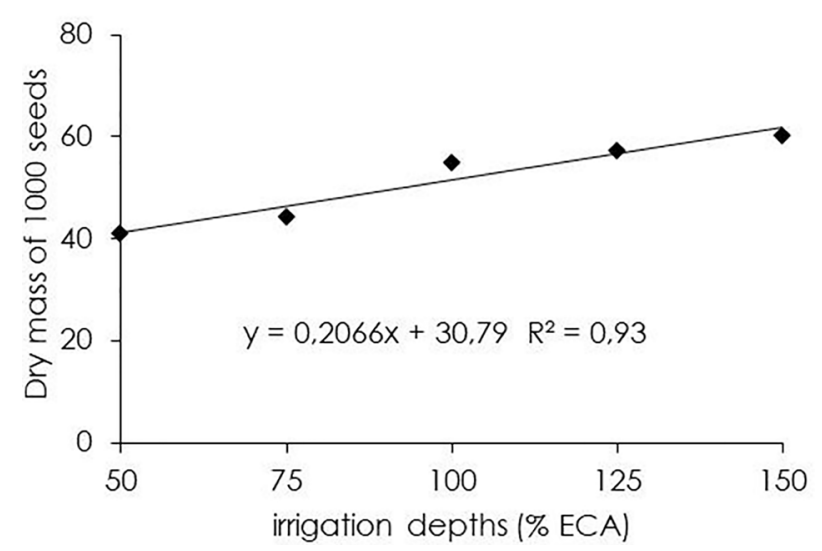

Figure 7. Mass of one thousand sunflower seeds as a function of the irrigation depths.

This result shows that the plants that received higher water replenishment provided greater grain filling, agree with Silva et al. (2014b), who affirmed that irrigation is one of the indispensable factors for agricultural production, and its lack or excess directly affects crop yield.

Similar effects to those observed in the present study were also verified by Silva et al. (2011) and Viana et al. (2012) at sunflower crop under different irrigation depths.

The effect of the interaction between irrigation depths and fertilizers on yield can be observed in Figure 8. The statistical model that best fit the data was the linear one for mineral fertilization (3195.8 $\mathrm{kg} \mathrm{ha}^{-1}$ ) and biofertilizer (3023.3 $\mathrm{kg} \mathrm{ha}^{-1}$ ), in the irrigation depth corresponding to $150 \%$ of the ECA and the quadratic polynomial model for the control treatment, with the maximum yield (2501.99 $\left.\mathrm{kg} \mathrm{ha}^{-1}\right)$ reached with an irrigation depth corresponding to $119.19 \%$ of the ECA. It should be noted that the sunflower crop behaves in a significant manner to the water 
replenishment in the soil through the practice of irrigation (Silva et al., 2011).

The plants fertilized with mineral fertilizers showed higher crop yield in relation to those that did not receive (control) and those that were fertilized with bovine biofertilizer. It is emphasized that the period in which the highest rate of nutrient absorption occurs in the sunflower crop, is in the phase immediately after the formation of the flower bud until the end of flowering period (Leite et al., 2005).

According to this result, Viana et al. (2012) also showed lower achene production potentials in the treatments submitted to the smallest irrigation depths. Working in field conditions, Gomes et al. (2012) reported higher results than those found in this study, with increases in sunflower yield with the increase of the applied water depths, observing $6,963 \mathrm{~kg} \mathrm{ha}^{-1}$ in the plants that received the highest irrigation depth $(400 \mathrm{~mm})$. Studies that show the effect of the interaction between irrigation and mineral fertilization were demonstrated by Viana et al. (2013) and Vasconcelos et al. (2015) in sunflower crop.

Regarding the effect of biofertilizer as an organic fertilizer on crop yield, Sousa et al. (2013) cultivating Jatropha in full sun, verified an increase in yield after one year of transplanting and Santos et al. (2014) cultivating melon in full sun also found a positive effect of this organic fertilizer.

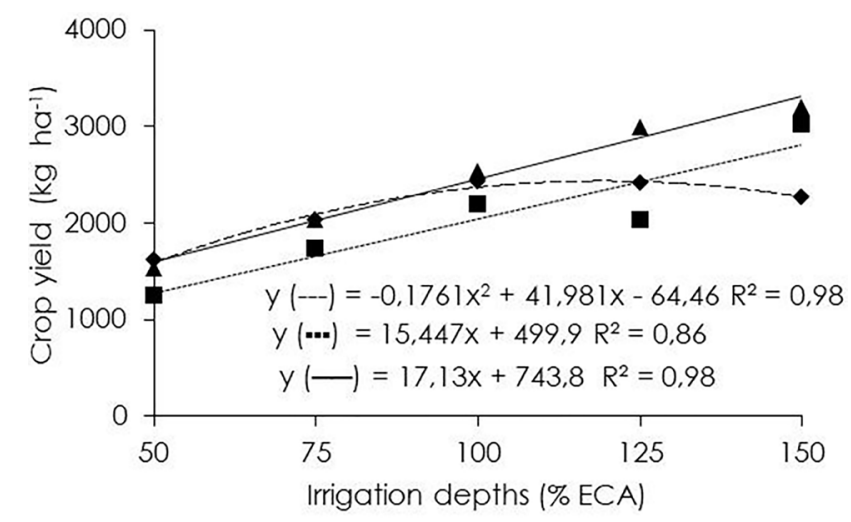

Figure 8. Sunflower crop yield, $(\bullet--)$ without fertilizers, ( $\bullet \cdot-\cdot)$ bovine biofertilizer and ( $\boldsymbol{\Delta}-$ ) mineral fertilizer, under different irrigation depths

\section{Conclusions}

Applying biofertilizer in sunflower plants provided similar increments to those provided by the application of mineral fertilizers in almost all the plant growth parameters, associated with the application of irrigation depths.

Higher irrigation depths provided better sunflower crop yields when associated with the application of mineral fertilizer and bovine biofertilizer.

\section{References}

Bilibio, C., Carvalho, J.A., Martins, M., Rezende, F.C., Freitas, E.A., Gomes, L.A.A. 2010. Desenvolvimento vegetativo e produtivo da berinjela submetida a diferentes tensões de água no solo. Revista Brasileira de Engenharia Agrícola e Ambiental 14: 730-735.

BRASIL. Ministério da Agricultura, do Abastecimento e da Reforma Agrária. Secretaria
Nacional de Defesa Agropecuária. Regras para análises de sementes. Brasília, DF, 2009.

Carvalho, C.M., Viana, T.V.A., Marinho; A.B., Lima Júnior, L.A., Valnir Júnior, M. 2013. Pinhão-manso: crescimento sob condições diferenciadas de irrigação e de adubação no semiárido nordestino. Revista Brasileira de Engenharia Agrícola e Ambiental 17: 487-496.

Dantas, M.S.M., Rolim, M.M., Pedrosa, E.M.R., Bezerra Neto, E., Silva, G.F., Silva, E.F.F. 2016. Accumulation of macronutrients in different parts of sunflower fertilized with cassava wastewater. Revista Brasileira de Engenharia Agrícola e Ambiental 7:630-636.

Freitas, C.A.S., Silva A.R.A., Bezerra F.M.L., Andrade, R.R., Mota F.S.B., Aquino, B.F. 2012. Crescimento da cultura do girassol irrigado com diferentes tipos de água e adubação nitrogenada. Revista Brasileira de Engenharia Agrícola e Ambiental, Campina Grande 16:10311039. 
Gomes, E.P., Fedri, G., Ávila. M.R., Biscaro G.A., Rezende'R.K.S., Jordan'R.A. 2012.

Produtividade de grãos, óleo e massa seca de girassol sob diferentes lâminas de irrigação suplementar. Revista Brasileira de Engenharia Agrícola e Ambiental, 16: 237-246.

Gomes, E.P., Ávila, M.R., Rickli, M.E., Petri, F., Fedri, G. 2010. Desenvolvimento e produtividade do girassol sob lâminas de irrigação em semeadura direta na região do Arenito Caivá, estado do Paraná. Irriga 15: 373-385.

Joner, G.; Metz, P. A. M.; Arboitte, M. Z.; Pizzuti, L. A. D.; Brondani, I. L.; Restle, J. 2011. Aspectos agronômicos e produtivos dos híbridos do girassol (Helianthus annus L.) Helio 251 e Helio 360. Ciência Animal Brasileira, 1: 266-273.

Leite, R.M.V.B.C., Brighenti, A.M., Castro, C. 2005. Girassol no Brasil. Londrina, Brasil, 641 p.

Lima, F.A., Sousa, G.G., Viana, T.V.A., Pinheiro Neto, L.G., Azevedo, B.M., Carvalho, C.M. 2013. Irrigação da cultura do gergelim em solo com biofertilizante bovino. Revista Brasileira de Agricultura Irrigada 7:102-111.

Lobo, T.F., Grassi Filho, H., BulllII, L.T., Kummerl, A.C.B. 2013. Efeito do lodo de esgoto e do nitrogênio nos fatores produtivos do girassol. Revista Brasileira de Engenharia Agrícola e Ambiental 17: 504-509.

Lobo, T. F.; Grassi Filho, H. 2007. Níveis de lodo de esgoto na produtividade do girassol. Revista Ciencia del Suelo e Nutricíon Vegetal 3: 16-25

Malavolta, E.; Vitti, G. C.; Oliveira, S. A. de. 1997. Avaliação do estado nutricional das plantas: Princípios e aplicações. Potafos, Piracicaba, Brasil. $319 \mathrm{p}$.

Nobre, R.G., Gheyi, H.R., Soares, F.A.L., Andrade, L.O., C.S. Nascimento, E.C.S. 2010. Produção do girassol sob diferentes lâminas com efluentes domésticos e adubação orgânica. Revista Brasileira de Engenharia Agrícola e Ambiental 14: p.747-754.

Oliveira, F. A. Oliveira, F.R.A., Campos, M.S., Oliveira, M.K.T., Medeiros, J. F.O., Prazeres da Silva, T.M.P. 2010. Interação entre salinidade e fontes de nitrogênio no desenvolvimento inicial da cultura do girassol. Revista Brasileira de Ciências Agrárias 4: p. 479-484.

Penteado, S.R. 2007. Adubação Orgânica: Compostos orgânicos e biofertilizantes. Edição do autor, Campinas, Brasil.162 p.

Prado, R.M. 2008. Nutrição de plantas. UNESP,
São Paulo, Brasil. 407 p.

Sá, F. V. S., Mesquita, E. F., Costa, J. D., Bertino, A. M. P., \& Araújo, J. L. 2015. Influência do gesso e biofertilizante nos atributos químicos de um solo salino-sódico e no crescimento inicial do girassol. Irriga 1: 46-59.

Santos, J.F., Wanderley, J.A.C., Sousa JÚNIOR, J.R. 2013. Produção de girassol submetido à adubação organomineral. Revista Agropecuária Científica no Semiárido 9:38-44.

Santos, A. P.G., Viana, T.V.A., Gomes-do-Ó, L.M., Azevedo, B.M., Santos, A.M. 2014. Produtividade e qualidade de frutos do meloeiro em função de tipos e doses de biofertilizantes. Revista Horticultura Brasileira 32: 409-416.

SILVA, F.A.S. ASSISTAT: Versão 7.7 beta. DEAGCTRN-UFCG - Atualizado em 01 de abril de 2014. Disponível em <http://www.assistat.com/indexp. html>. Acessado em: 20 de junho de 2014a.

Silva, A.R.A., Bezerra' F.M.L., Sousa C.C.M., Pereira Filho J.V., Freitas, C.A.S. 2011. Desempenho de cultivares de girassol sob diferentes lâminas de irrigação no Vale do Curu. Revista Ciência Agronômica 42: 57-64.

Silva, M.L., Farias, M.A., Morais, A.R., Andrade, G.P., Lima, E.M.C. 2007. Crescimento e produtividade do girassol cultivado na entressafra com diferentes lâminas de água. Revista Brasileira de Engenharia Agrícola e Ambiental 11: 482-488.

Silva, F. L. B.; Lacerda, C. F.; Neves, A. L. R.; Sousa, G. G.;Sousa, C. H. C.; Ferreira, F. J. 2013. Irrigação com águas salinas e uso de biofertilizante bovino nas trocas gasosas e produtividade de feijãocaupi. Irriga, n: 304-317.

Silva, S.S., Wanderley, J.A.C., Bezerra, J.M., Chaves, L.H.G., Silva, A.A.R. 2014. Crescimento do girassol com níveis de reposição hídrica e adubação potássica. Agropecuária Científica no Semiárido 4:104-110b.

Sousa, G.G., Viana, T.V.A., Braga, E.S., Azevedo, B.M., Marinho, A.B., Borges, F.R.M. 2013. Fertirrigação com biofertilizante bovino: efeitos no crescimento, trocas gasosas e na produtividade do pinhão-manso. Revista Brasileira de Ciências Agrárias 8: 503-509.

Souza, R.M., Nobre, R.G., Gheyi, H.R., Dias, N.S., Soares, F.A.L. 2010. Utilização de água residuária e de adubação orgânica no cultivo do girassol. Revista Caatinga 23: 125-133.

Vasconcelos, D.V., Azevedo, B.M., Fernandes, C.N.V., Pinto, O.R.O., Viana, T.V.A., Mesquita, 
J.B.R. 2015. Métodos de aplicação e doses de nitrogênio para a cultura do girassol 4: 667-679

Viana, T.V.A., Lima, A.D., Marinho, A.B., Duarte, J.M.L., Azevedo, B.M., Costa, S.C. 2012. Lâminas de irrigação e coberturas do solo na cultura do girassol, sob condições semiáridas. Irriga 17:126136. 